\title{
ON THE ROLE OF VISUALISATION IN UNDERSTANDING PHRASEOLOGISMS ON THE EXAMPLE OF COMMERCIALS ${ }^{1}$
}

\author{
Anneli Baran
}

\begin{abstract}
Phraseologisms are linguistic units characterised by figurativeness or usage of metaphors. But what exactly is figurativeness? In the case of a linguistic unit, it is a quality instigating visual imagery. So, the direct meaning of a great part of phraseologisms is so figurative that we can easily visualise it. It is obvious that these individual visualisations help us understand an unfamiliar expression. The fact that while interpreting phraseologisms, language users may consciously proceed from mental images, is also confirmed by psycholinguistic experiments. This article dwells upon visualisation of metaphorical expressions as a means of conveying messages in advertisements and their reception or interpretation.
\end{abstract}

Keywords: phraseologisms, iconicity, mental lexicon, iconic motivation, figurativeness

\section{MOTIVATION IN PHRASEOLOGISMS ${ }^{2}$}

When discussing the nature of the phraseological unit, we usually emphasise such features as stability, figurativeness, motivation, and idiomaticity; yet, practically always we have to accentuate the relativity of these parameters as well as their affectedness by subjective factors. Therefore we cannot say that these characteristics are similarly valid for all phraseological units.

For more than half a century, the core notion in phraseological studies has definitely been motivation. Discussions about the notion of motivation (validity) in phraseological research have lasted nearly as long. The criterion of motivation, which was introduced into the classification of phraseological units by Russian linguist and academician Viktor Vinogradov, is largely regarded as subjective in modern phraseology, and is sometimes even discarded as barely suitable for analysis. However, this is an essential notion adding to the nature of the phraseologism, and therefore I would like to discuss it somewhat further.

Starting from Vinogradov, phraseologisms have roughly been divided into two groups on the basis of the motivation criterion: phraseological fusions or 
opaque phraseologisms and phraseological unities or transparent phraseologisms. These two main types include units that can be differentiated only on the basis of the motivation criterion. The units in the first group are demotivated whereas the ones in the second group "implicitly refer to motivation and semantic divisibility" (Vinogradov 1947: 352-353). This is where subjectivity sets in, as, except for a few obvious cases, the level of motivation is not measurable by linguistic means.

The current definition of motivation in phraseological research originates from phraseologist Harald Burger: "Motivation means that the meaning of a phraseologism can be understood by way of the free meaning of the unit or the meanings of its component parts" (2003: 66). Similarly to Vinogradov, Burger also emphasises that motivation is inseparable from semantic idiomaticity: the stronger the motivation of the phraseologism, the weaker its idiomaticity (and vice versa). So, motivation is in inverse relationship with idiomaticity, and therefore an unavoidable concept - they are interpreted through each other. Burger regards the motivation level as the relationship between the whole and its components in the chain of signs (1973: $26 \mathrm{ff}$.). This chain of signs can be either motivated or demotivated. In the first case, the meaning of the whole can be 'derived' from the meanings of its component parts, as formal and semantic structures are isomorphic, whereas in the second case it is not possible. As regards idiomaticity, idioms in the narrower sense of the word are demotivated word sequences, whereas idioms in a broader sense are weakly motivated, and completely motivated sequences are not idiomatic. Hence - the weaker the motivation of the word sequence, the more idiomatic it is. However, Burger also emphasises that language users have a different understanding of not only the motivation but also the relationship between motivation and idioms.

In addition to Vinogradov and Burger, two more researchers of phraseology - Dmitrij Dobrovol'skij and Elisabeth Piirainen - have made an attempt to delve into the problems of motivation in phraseologisms. In cooperation, they have authored three monographs: Symbole in Sprache und Kultur. Studien zur Phraseologie aus kultursemiotischer Perspektive (1996), Figurative Language: Cross-Cultural and Cross-Linguistic Perspectives (2005) and Zur Theorie der Phraseologie. Kognitive und kulturelle Aspekte (2009).

Dobrovol'skij and Piirainen's treatment of different types of motivation in phraseologisms is based on semiotic concepts - arbitrariness, iconicity and symbolicness. ${ }^{3}$ As they have argued: although the creation of symbolic units can be regarded as spontaneous and unpredictable, it is not entirely arbitrary, as it is partly defined by certain regularities (Dobrovol'skij \& Piirainen 2005: 183 ff.). Here I would like to emphasise their contention that conventional symbolic units are concurrently arbitrary and non-arbitrary (ibid.: $184 \mathrm{ff}$.). 
By relating arbitrariness to the cognitive theory of conceptual understanding, they maintained that phraseologisms are arbitrary in the sense that even if the formation of a symbolic unit is defined by a conceptual structure, the so-called semantic result is not entirely predictable - the level of predictability depends on the level of motivational transparency. ${ }^{4}$ Yet, they are non-arbitrary in a sense that there exist logical connections between the conceptual input and output, this way motivating links between the knowledge plane, which is partly fixated in lexical structure, and the actual or figurative meaning. This in turn means that if we have knowledge about both the source and the meaning, we can imagine which cognitive processes lead to a certain semantic result; this is why the figurative unit seems to be prone to motivation. ${ }^{5}$

As was mentioned above, it is obvious that not all phraseological units can be motivated to the same degree. Yet, in addition to the distinction between motivation and demotivation, we can distinguish articulation inside motivation. Dobrovol'skij and Piirainen suggest that there exists motivation based on form and motivation based on meaning, or iconic and symbolic motivation. ${ }^{6}$ These are motivation types, not classes of phraseologisms, i.e., there are phraseologisms that are motivated both semantically and formally (Dobrovol'skij \& Piirainen 1996: 107). The best examples here are comparisons and pair formulas in the intensifying function. ${ }^{7}$ Also, the aforementioned authors claim it to be obvious that idiomatic expressions reverberate in the mental lexicon as a whole, as they are not produced without prior knowledge that such idioms can be exploited. So it is not meaning transmission in the traditional meaning but rather "an operation of knowledge structure" (Operationen mit den Wissensstrukturen) (Dobrovol'skij \& Piirainen 1996: 111). Hereby they base their viewpoints on Lakoffian theory: metaphorically motivated phraseologisms are elaborated on the basis of everyday knowledge, frame/script/schema knowledge or concept structure, or some other conceptual structure knowledge. According to Dobrovol'skij and Piirainen, the actual meaning of idioms emanates from the frame or script, i.e., cognitive structure, or associative context due to certain conceptual operations (2005: $164 \mathrm{ff}$.). So, relevant knowledge structures from primary frames are projected on the target frame, this way enabling the motivated interpretation of the combination of form and content. According to these researchers, the advantage of the tools of such meta-language interpretation as compared to the concept of traditional meaning transmission is the possibility to discuss not only explicit but also implicit elements 'generated' by idioms (hence the aforementioned notion 'inner form'). Besides the semantic autonomy of its components, the imagery phenomenon also comprises a reference to the semantic divisibility of phraseological meaning and therefore it is not possible to analyse imagery without including the meanings of individual components 
in the phraseological meaning. Dobrolovol'skij and Piirainen are of the opinion that for an adequate semantic description of an idiom we have to include the significant elements of the inner form ${ }^{8}$ in order to explain the meaning. This fact also testifies to the complexity of the motivation of a phraseological unit.

Yet, these elements of deep structure are not necessarily significant for concluding and therefore, for motivation. As the selection of features is more or less arbitrary, the elaboration of the deduction process must, according to Dobrovol'skij and Piirainen, proceed from the conceptual structure as a whole. However, the processes corresponding to motivation can be associated with the frame (static conceptual structure) or script (dynamic procedural knowledge structure) to a different extent. Dobrovol'skij in his book co-authored with Anatoli Baranov emphasises that not all phraseologisms are similarly understandable, i.e., their interpretation does not take place only on one level but mental images in phraseologisms must be viewed on three different levels (Baranov \& Dobrovol'skij 2008: 115):

- Individual-based quasi-visual mental images;

- Knowledge level (i.e., frames, scripts, schema);

- Conceptual-metaphoric level.

The aforementioned two researchers hold that until today the second level has been practically ignored by phraseologists. In their opinion, one of the reasons is the fact that modelling striving for universality eliminates cultural linguistic specificity. On the other hand, pictorial images are empirically better understandable than generalised cognitive or conceptual metaphors.

\section{FIGURATIVENESS OR ICONICITY?}

The concept of motivation is closely associated with idiomaticity, and the latter in turn with figurativeness. But what exactly is figurativeness? ${ }^{9}$

German scholarship, which has been leading the way in phraseology for quite a while (see, e.g., Burger 2003; Häcki Buhofer 1999), distinguishes between two notions: Bildlichkeit (imagery) used in a more general sense and Bildhaftigkeit as imaginarity and visuality. ${ }^{10}$ The latter can be understood as a quality of the linguistic sign to instigate concrete imagery or visualisation. Figurative words and expressions are the ones that can easily be linked to a concrete situation. So, in the case of some idioms, both the component parts and the direct meaning of the expression are so figurative (Ger. bildhaft) that the whole event can be imagined as visual-concrete. Dobrovol'skij and Baranov call these images quasi-visual. According to the experiments made by the same researchers, we 
can proceed from them under certain circumstances, and they may (although do not need to) be associated with the actual meanings of the respective idioms (Baranov \& Dobrovol'skij 2008: 112). Yet, this activity based on associations can differ by person and usage relations.

Undoubtedly, metaphors based on pictoriality are linguistic images closely associated with iconicity. This idea was introduced by Yuri Lotman, who argued that an icon is a metaphor (1981: 16), hereby bearing in mind an icon as a painted image in the literal meaning of the word, with complex non-identity relationships between its form and content.

The approach proceeding from iconicity has become a matter of increasing interest in phraseology studies only in recent years; as a rule, phraseological units have been discussed as figurative. In addition to Dobrovol'skij and Piirainen, the notion of iconicity ${ }^{11}$ in phraseology has recently been studied in more detail also by Ken Farø, although from a somewhat different viewpoint. Farø also treats iconicity as a specific case of motivation, yet differentiating between iconicity and iconography, preferring the latter as a more precisely defined and less subjective to figurativeness, which is widely exploited in phraseology (2006a: $62 \mathrm{ff}$.). He defines iconography as a potential of the idiom to conjure up a mental vision on the basis of direct interpretation. However, according to Farø, iconography is not the same as figurativeness, which is traditionally understood as a quality generating a visual image - therefore, not a psychological but rather a semiotic-psychological quality of a linguistic sign (semiotisch-psychologische Eigenschaft) (Farø 2006a). While in iconography, a mental image is created by way of literal or direct understanding of the idiom, then in the case of iconicity, the idiom 'reflects' its content through its form. Although Farø maintains that phraseologisms are iconic as they 'reflect' their content and are therefore semantically transparent for the language user who is familiar with their meanings, he finds that it is groß granulierten Abbildung (an extremely coarse image) (Farø 2006a: 63). Just like Dobrovol'skij and Piirainen, Farø also argues that the content that is made transparent forms only a small part of the actual meaning of the idiom, i.e., in the case of iconicity, we cannot claim that content and form are in mutual conformity. Therefore, iconicity does not refer to a relationship between all the elements of form and content because it constitutes only a small part of the 'actual' content, i.e., of all the qualities of the idiom.

Dobrovol'skij, who has actively been engaged in defining the concept of motivation, considers the identification of figurativeness with semantic ambiguity or motivation as incorrect (1997: 47). Correlation between idioms and motivation on the basis of semantic ambiguity is not always completely clear. An idiom can be made up of semantically ill-formed strings, have only figurative meaning 
and still be motivated. So, the precondition for figurativeness is not semantic ambiguity, as there exist also idioms with no literal meaning, whose so-called figurative content is absurd. Or, as Dobrovol'skij emphasises, the content plane of idioms often provides an absurd description of events and actions impossible in a real world, therewith breaking the laws of common logic: the word components that are formally joined on the basis of syntactic models, do not form a meaning relating to the world picture but result in funny associations. As Baranov and Dobrovol'skij emphasise, in these cases visualisation is useless and we have to draw on cognitive knowledge (2008: 112-113). ${ }^{12}$ These researchers claim that, despite the aforementioned quasi-pictorial/visual images, each motivated idiom has a certain meaning attached to it, which emanates from the suitable conceptual structure, frame or schema and cannot be consciously regulated. As mentioned above, the same was also postulated by Dobrovol'skij and Piirainen in their research.

In conclusion we can say that there are different conceptions about the importance of the so-called inner picture (or figurative meaning component) in the cognitive process; yet, we should proceed from the fact that visual images provide at least as good (if not even better) access to conceptions as notions. It is clear that phraseologisms can offer, in addition to phraseological meaning, also starting points for visual images that improve understanding, on the one hand making it more concrete, but on the other hand introducing additional elements of meaning, which have nothing to do with phraseological meaning. So people's visions enable varied perception of phraseological meanings and are not 'prescribed' but allow for different individual interpretations.

\section{VISUALISATION AS MOTIVATION FACILITATOR FROM PSYCHOLINGUISTIC ASPECT}

The previous chapter presented the ideas of linguists-phraseologists about motivation and its role in interpreting phraseological expressions. On the other hand, psycholinguists have also been actively engaged in interpreting figurativeness and the role of visualisation therein. Yet, rather, they are narrowly focused on idioms, weighing the correlation between opaqueness and transparency only in the case of such linguistic units with complex motivation.

For a long time, one of the most renowned researchers in this field has been Raymond W. Gibbs Jr., whose research based on psycholinguistic experiments has proved that motivational images have a psychological-cognitive reality of motivation (2002: 452). If the initial relationships fade, it has a negative impact on motivation; yet, some new relationships can emerge and the expression can 
still acquire motivation. However, it becomes obvious that search for motivation brings along changes in interpretation. The most essential observation that has been pointed out by the same researcher in idiom-studies is that the interpretation process does not pass an intermediate stage - direct meaning but immediately decides in favour of the figurative meaning; Gibbs calls this kind of model the direct access model/view/hypothesis (1994). This model is based on the idea that expressions along with their meanings have been stored in the mental lexicon and they always appear as the first choice. Gibbs, who thinks that there is no reason to consider the direct meaning as psychologically primary, i.e., something that always precedes the following stages in the course of processing (1989: 249), has emphasised that this is simply about various results of the linguistic interpretation process - this is so-called psychological reality. The metaphor is used to forward different vague, indirect meanings, whose reconstruction is strongly restricted by the context shared by the speaker and the listener. People's intuitions about the mental images behind idioms are, according to Gibbs, a co-product of specific conceptual metaphors motivating the figurative meaning of idioms. Although in reality, idioms have two types of meanings - direct and figurative, it is namely the conceptual metaphor that motivates the image in the idiom and activates it automatically. According to this approach, automatism enables to overlook the concrete direct meaning.

Some researchers have also made attempts to oppose Gibbs in certain aspects. Cristina Cacciari and Samuel Glucksberg have noted that interpretation is more complicated especially in the case of the idioms that denote concrete activities also in the direct meaning of the word, which may, but need not be semantically associated with the figurative meaning of the idiom (1995: 46). These researchers regard it as highly probable that in such cases a visual image can emerge, which reflects direct rather than idiomatic meaning (or associates rather with so-called direct-meaning scene, which largely depends on how automatic the interpretation of the respective idiom is). However, Cacciari and Glucksberg do not treat the interpretation and usage of idioms as merely activating of the meanings of words, but also take into account the aspect of creativity, i.e., they are exploited in a suitable context. In case several interpretations are possible for idioms, a suitable one is selected on the basis of contextual and situative information, so that in this concrete meaning unambiguous interpretation is possible.

However, Gibbs does not agree to the contention attributed to him, according to which ordinary speaker's mental images about idioms are based on merely figurative meaning of the idiom or even on conceptual metaphors that underlie these idioms. Similarly to the experiments carried out by Cacciari and Glucksberg, Gibbs's own experiments also prove that initially, people form a 
very concrete image about an idiom, which can be understood literally. Mental images for different idioms are in accordance with each other, and this integrity, according to Gibbs, is not based on figurative meaning but on the fact that the motivation of each idiom is supported by a similar conceptual metaphor. In his article co-authored with Nandini Nayak (Nayak \& Gibbs 1990: 322), Gibbs has summarised the results of his experiments, claiming that people are able not only to ascertain the metaphoric similarity between idioms, but they also use this knowledge when they have to make decisions about the suitability of idioms in certain contexts - the conceptual coherence between the idiom and its surrounding context has a direct influence on the processing speed of idioms. Tests indicate that although conceptual metaphors influence people's decisions about the suitability of an idiom in different contexts, they are not accessible in on-line interpretation of idioms. Even if test persons were asked for a figurative paraphrase of the metaphor, the answers still provided the ones in contradiction to the relating conceptual metaphor. However, Gibbs emphasises (1998: 105) that neither he nor his colleagues have claimed that conceptual metaphors are not readily accessible in the interpretation process of idioms, i.e., when the participants have not completed the interpretation of figurative phrases, but this process should be interpreted as a clue indicating that conceptual metaphors are activated either simultaneously or right after the idiom has been understood.

Certainly, when interpreting idioms, conceptual metaphors are much more easily accessed due to highly conventionalised close connection between the idiom and the conceptual metaphor than is the case with a random linguistic metaphor. Moreover, the majority of conceptual metaphors have yielded different idiomatic/conventional expressions, i.e., conceptual metaphors underlie cognitive processes within which figurative speech is interpreted (Gibbs 1998: 106-107): more frequent use of certain idioms and attributing motivation to them by way of conceptual metaphors can make the latter more salient and more accessible in a situation in which idioms are heard or read. ${ }^{13}$ Gibbs emphasises that regarding something as primary or secondary does not necessarily imply different cognitive processes; it is rather an issue of salience. Gibbs holds that the fact that people automatically analyse the literal meanings of the words in an expression would need further investigation, within which we should discard the interpretation of literalness in the linguistic meaning.

Gibbs also reappraised his approach ten years later, claiming that the hypotheses associated with conceptual understanding that he formulated in 1998 were carried by the idea of treating the interaction of different aspects of metaphoric models and language use and -understanding as hierarchical. Based on this knowledge, in his research co-authored with Markus Tendahl, he finds it 
more sensible to proceed in the interpretation of language understanding instead of conceptual metaphor theory from blend theory or the notion of conceptual blending (Tendahl \& Gibbs 2008: 1843).

In recent years, ongoing attempts have been made to ascertain the importance of mental images in the understanding and processing of figurative language. Numerous tests have been carried out, above all, among those who learn English as a foreign language at an advanced level. Although methodology for drawing adequate conclusions is only being developed, these tests prove unambiguously that interpretation of images is highly individual. Yet, as indicated by the results of experiments, visualisation, unlike verbal stimuli (e.g. word-for-word descriptions), facilitates the interpretation of completely unfamiliar idioms (see Boers et al. 2009), which may but need not contribute to interpretation. Cognitive efforts are also influenced by etymological explanations. In the case of opaque idioms it might be of avail; yet, does not need to be (Boers et al. 2009; Szczepaniak \& Lew 2011). In addition, monosemic words in the idiom can be interpreted differently or the source-domain belonging of an idiomatic expression cannot be defined unambiguously. Yet, my own experience with the phraseology questionnaire proved the opposite trend: when interpreting an image in an unfamiliar expression, people rather rely on associative links and the explanation given is related to the so-called actual meaning of the expression to a smaller or greater extent (Baran 2008). However, these were native speakers for whom interpretation was certainly easier than for those with no command of the language. It is obvious that, in order to understand figurative speech, just good or even excellent knowledge of another language is not enough. The words that have so-called associative meaning in a set expression can be polysemic in out of context use - this is a facet that makes the interpretation of a phraseological image complicated for a non-native speaker. Some researchers even refer to this as a special kind of phraseological metaphor (see Naciscione 2010); however, in my opinion this distinction is not necessary.

Understanding of a language also implies the perception of the cultural context. Deficiency in this sphere could be compensated by visualising the image as a clue. This is especially frequent in modern advertising, which, whether we want it or not, as a component of public space occupies a central place in our lives. In addition to ordinary places of occurrence (so-called outdoor or open city space, printed media, television, radio), advertising industry increasingly uses the Internet environment, demonstrating flexibility by taking advantage of different multimodal means. Visualisation as the central element of advertising operates as a reference to cohesion, which allows for interpretation while the text is not understandable or an object of aberrant decoding. Or, as Charles Forceville, exploring figurativeness and pictoriality, has emphasised in case 
of advertisements, visual contextualisation facilitates the understanding of verbal metaphors (1994: 6).

The following examples represent the combination of text and picture. ${ }^{14}$ The picture operates as a kind of mnemonic device facilitating understanding - the expression is contextualised. Also, the picture can certainly be 'manipulated': some aspects can be accentuated whereas some others that are nearly equivalent can just be deliberately ignored or regarded as not important. A similar tendency to visualise can also be observed in internet humour, and it is especially expressive in the case of demotivators: see, for instance, comparative studies by Anneli Baran (2012) and Tomasz Piekot (2012) on the example of Estonian and Polish material. Although interpretation is directed consciously (or at least attempts are made to do so), reception is largely cognitive, i.e., the construction of meanings is individual. As experiments have proved, complete consensus about meanings is extremely rare (Szczepaniak \& Lew 2011). Also, it is obvious that, for the purpose of cognitive economy, the first thing emerging in memory is offered as a solution. For a long time, researchers have proceeded from the proposition that non-typical (phraseology-specific) cognitive efforts are made to interpret phraseologisms. However, this conception contradicts reproductiveness inherent in phraseologisms, which undoubtedly makes cognitive expenditure more economic (Häcki Buhofer 1999). As a solution, psycholinguists have recommended to view the acquisition of idioms as part of a wider phenomenon - as cognitive mechanisms that serve as the basis for semantic competence and linguistic understanding (Levorato \& Cacciari 1999: 54).

\section{VISUALISATION OF PHRASEOLOGISMS IN ADVERTISEMENTS}

Advertising as a phenomenon of the mass media has become part and parcel of modern culture. Its impact seems to be the strongest in the youth culture, which was also clearly demonstrated by the school lore competition in 2007. ${ }^{15}$

Commercials have become part of the public space; different media channels (including the Internet) are used to forward them and they can also be encountered in the street. More and more often, commercials aim at influencing rather than informing. Modern commercials can be seen everywhere, i.e., to forward the same message, different means are used, which guarantees more extensive impact. Due to wide spread, advertising has become a significant communication phenomenon.

One of the advertising strategies is effect-based texts ${ }^{16}$, which apply for humour, pun or other elements of unexpectedness. Besides the text, the visual part is one of the main elements of an advertisement. Its function is to make 
the narrative in the message more expressive, whereas it has to be associated with the main idea of the commercial message. Or, as has been formulated in advertising psychology, if one of the elements in the reception of visual advertising - looking at the image, reading the slogan, reading the body of the text - should fail, the failure is complete (Bachmann 2005: 55). Therefore, for achieving the primary purpose of advertising - its psychological impact - all the components are similarly significant.

Although the following examples representing mainly printed advertising have been chosen in view of demonstrating the possibility of purposeful visualisation of phraseologisms despite the ambiguity of the image (or, due to it, for that matter), these also eloquently testify to the increasing importance of visuality. According to opinion polls, the youth is primarily interested in animated multimodal commercials rather than merely static published or outdoor advertising posters. ${ }^{17}$ Although there are always exceptions, the visual side around the text is still the most important element of commercials. As advertising research has proved, people prefer commercials with 70-80\% covered by the visual (Bachmann 2005: 67). Therefore, only up to $30 \%$ of the total space of the advertisement remains for the verbal part.

It is understandable that in modern society, in which written word has become dominant, copywriters are trying to make text messages more expressive by adding effectual visualisation. As several renowned phraseologists have demonstrated in their researches into advertising language, phraseological expressions are allegedly the best for this purpose, as they act as eye-catchers due to their colourfulness and certain familiarity (see, e.g., Röhrich 1978: 87; Fiedler 2010: 6). So, visual set expressions are attributed some features that are rather relative in view of more recent studies. The more remarkable is the fact that practitioners - in this case copywriters - dare to forward their messages by the expressions that by today have lost their topicality and motivation.

Advertising research reveals that copywriters focus on a particular target group. However, they cannot afford ignoring people outside this group who as consumers also belong to the same public space. Therefore, we all as 'recipients' can interpret the messages that have previously been creatively interpreted by their creators. This is a kind of double interpretation, as something that was given a different content by someone can be re-interpreted and not necessarily in the same frame. This can bring along increasing expressiveness and comic impact. In quite a few respects it is similar to the incongruity solution suggested by humour theoreticians (see Krikmann 2004: $130 \mathrm{ff}$.): interpretation different from so-called prototype usage (or non-prototype usage) in turn enables new marked interpretations and impacts therefrom. In advertising these purposeful modifications acquire additional meanings on different levels (semantic, 
functional, etc.). Yet, the understanding of such deviations presupposes certain competence, especially due to their usage in insufficient linguistic context. ${ }^{18}$ Traditionally, the communicativeness of pictures is regarded as more universal than verbal language; yet, at closer inspection we learn that the universal comprehensibility inherent in pictures is valid only within a concrete cultural context (Laaniste 2005: 618; Hallsteinsdóttir 2011). It is obvious that in order to understand the pictorial images connecting both figurative language use and visual language, it does not suffice to master another language. This is a fact that those who create meanings for achieving some goals do not always seem to be aware of. ${ }^{19}$ Here we can but agree to Peeter Torop's statement about the complex relationship between the verbal and the visual, arguing that "the relationship between the text and the image is a central media-analytical problem, which is also a significant issue of cultural self-description and self-understanding" (Torop 2008: 731).

Below I analyse some examples of visualising phraseologisms and the relationship between the text and the picture in local advertising. ${ }^{20}$

Phraseologisms exploited in advertising are often changed both in form and in content. The notion of remotivation has been used in connection with emerging modifications (Varga 2010). This is a term that, for example Burger, suggests should be avoided as inaccurate: it does not embrace reversing the 'genetic process' but rather the activation of a possible word-for-word modification of a phraseologism or some aspects of one or several of its components (Burger 2003: 68). He argues that instead of remotivation, we should still discuss changes depending on either a different motivation or the actualisation of a word-forword variation. This article is also based on the latter opinion.

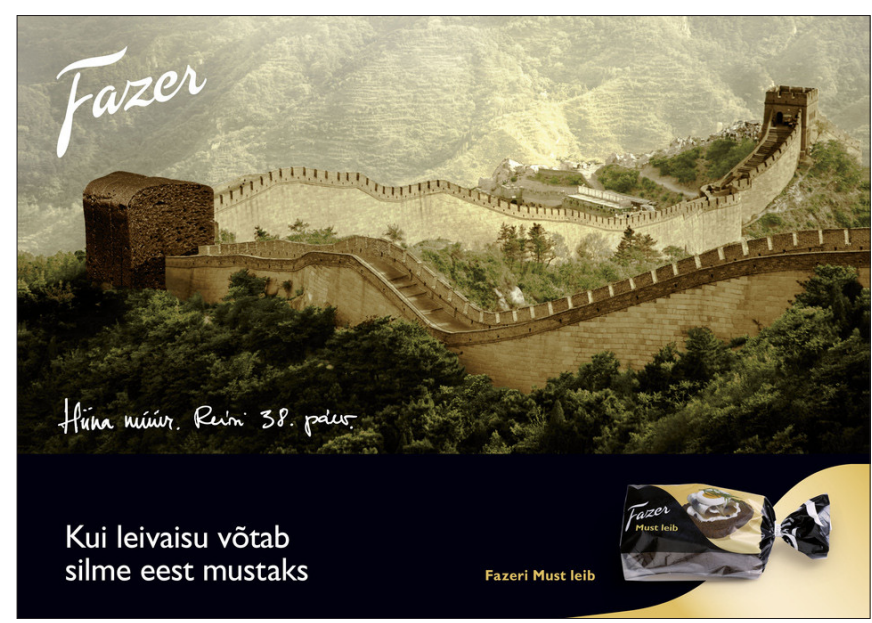

Figure 1. Advertisement for Fazer black bread, saying: When craving after black bread makes you black out. 
In the first example (Fig. 1), on the one hand, a well-known set expression and, on the other, symbols and stereotypes have been used to deliver the message. In the text part the traditional figurative expression silme ees läks mustaks ('everything went black before the eyes'; blacked out) has been used. The expression has been somewhat altered: instead of the verb minema ('go') the verb võtma ('make, render') in the meaning 'cause to be or become' has been used. ${ }^{21}$ An earlier record in the database of Estonian sayings and phraseologisms (EKFA) dates back to 1937: Keik ilm lää silmade ees mustaks ('the entire world turned black before the eyes'). Actually, the original dates back to a farther past, as already in 1840 Friedrich Reinhold Kreutzwald, the 'father' of Estonian national literature, used it in his story Wina-katk (Vodka plague):

Juhtus ükskord emmaga, kes nisammoti jowastano olli, rängaste rido; emma söimas ja torrises ni kaua wasto, kunni issa irmsal kombel needma ja wanduma akkas, et minno ihhokarwad püsti töusid ja köik mul silmade ees mustaks läks. ${ }^{22}$

Once there was a great row with Mother, who was also drunk; she kept scolding and grumbling until Father started to curse and swear, so that I had gooseflesh all over and blacked out.

According to source materials, this expression is most probably a German loan: jem. wird es schwarz vor den Augen (Röhrich 1973), which was adopted into Estonian and has been in use already for centuries. Actually, at first sight, the connection between the text and the image in this advertisement is practically hidden. The advertising sequence compares the traditional Estonian bread product with world-famous structures, such as the Great Wall of China and Stonehenge in Great Britain). The copywriters have probably been influenced by the lexeme must ('black'): must leib > silme eest läks mustaks ('black bread > everything went black before the eyes'). Here we have to admit that the authors are skilfully playing both on verbal and visual level as well as with cultural symbols: black bread essential for Estonians has been juxtaposed with the symbols of world renown. Also, it makes fun of stereotype thinking: if an Estonian is tired of travelling abroad, they can see only one thing in their mind's eye. This idea was also expressed in the TV-commercial, in which a girl returning to homeland goes right from the airport to a store to buy black bread, as this is something that she has missed very much while away from home:

After returning from a long trip, craving after black bread is most desperate. Black bread, sour cream and salted herring could even be sold as a package. This is the food that makes you feel you have arrived home. As by now the majority of Estonians have been abroad, this feeling is familiar to many. Congratulations to the creators on a good advert! I believe 
that this commercial will find its way into the hearts of the black bread people. (Henri Jääger 2008)

The Finnish-origin producer of the bread has a product presentation on its homepage featuring the same rhetoric:

Much has been spoken about yearning for Estonian black bread while away from home. It is not just the bread that you are used to eating. It is a symbol of homely food that people miss the most while being abroad. (Fazer 2012)

Although certain platitude constitutes a natural part of both the advertisement and the traditional expression, a much more effective result can be achieved by a creative approach to both. As was manifest above, product promotion can be visually compatible with cultural traditions and symbols. In the case of bread products, the same symbols have also been exploited by other manufacturers in this sphere. Yet, it is obvious that, with no clear perception of cultural context, the message in the advert remains quite vague. ${ }^{23}$

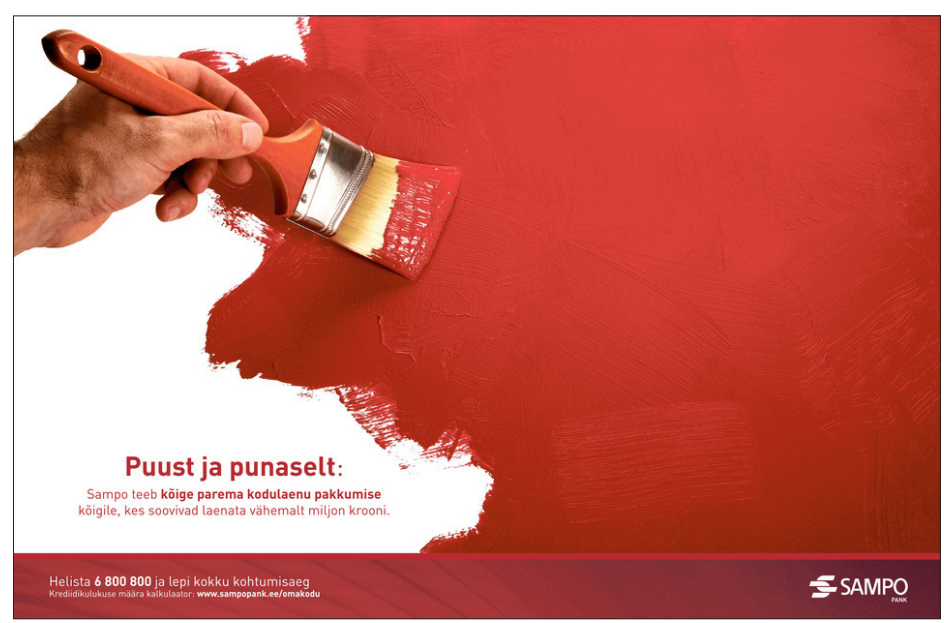

Figure 2. Advertisement for Sampo home loan.

The second example (Fig. 2) is a banking commercial with a very simple message: we are better than anybody else (Sampo makes the best loan offer). The commercial is based on the visualisation of the word-for-word or lexical content of the well-known expression tee puust ette ja värvi punaseks ('make out of wood and paint it red') (in the earliest records in the EKFA from the 1960s: tee võ $i$ puust ette ('you can make it even out of wood'); the texts with the addition of 
värvi punaseks ('paint it red') date back to a more recent period); brush and paint are the attributes that are directly associated with painting. In addition, the image of a hand swinging the brush along an imaginary surface presents a process, i.e., something is born just there and then. Visualisation is probably used also for an additional effect: red as an intensive eye-catching colour. Although red as a symbol is generally universal, this colour is also ambivalent to a certain extent: it has both positive and negative connotations in different cultures. ${ }^{24}$ In Estonian as well as Finnish tradition, red has historically had a positive role (Sarapik 1998: 23-25); yet, in Estonia as a post-socialist society this colour has also been marred by negative shades. Therefore, if we fail to consider all the meanings, the impact of a visual message can be unexpectedly different. Similarly to the previous example, this is also a foreign company - a facet characteristic of nearly all the advertisements presented here - who in its product promotion has made use of traditional Estonian set expressions and tried to make them visually more expressive.

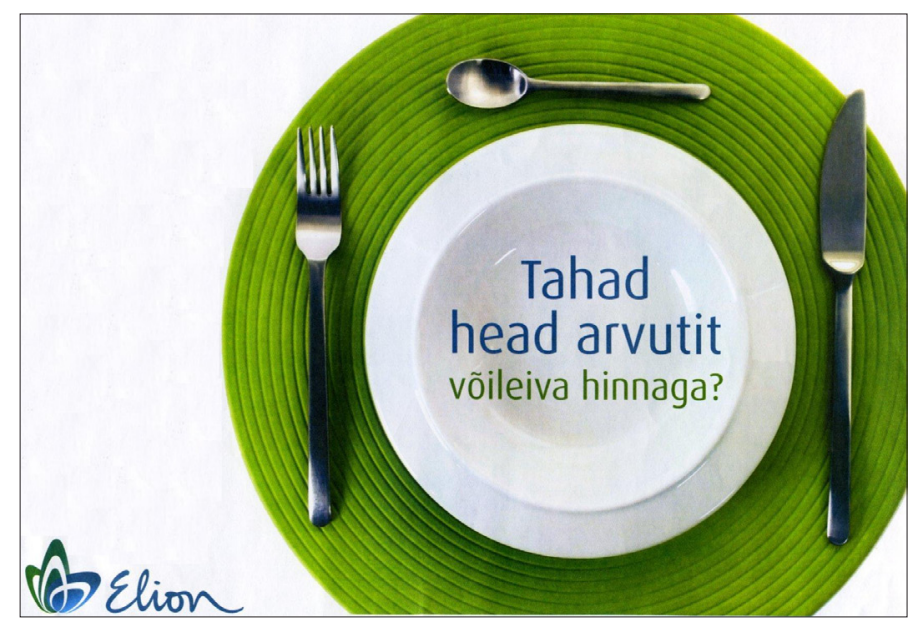

Figure 3. Advertisement for Elion economy campaign, saying: Do you want a good computer for the price of a sandwich?

The third example of advertising has made use of an expression well known in Estonian. The meaning of the devaluative adverbial phrase võileivahinna eest ('for the price of a sandwich') is 'extremely cheap, for a song'. It is a really old expression, which is also suggested by the texts in the EKFA; the earliest of them date from the end of the 19th century (1889). However, the phrasing in them is somewhat different - võileiva eest ('for a sandwich') (e.g. Andis võileiva iest ära. 'Gave it away for a sandwich.'). Only from the 1940s the expression 
started to be used together with the lexical component hind ('price'). In my opinion this expression could also have originally been a loan from German: etw. für ein Butterbrot hingegeben (Röhrich 1973).

The visualisation in the advert uses scarce means and refers to the lexical content of the expression only indirectly (tableware set out on the table), avoiding explicit description. Although the objects exploited in the advert have only rather a vague connection to the literal meaning of the phraseologism, the message, due to the familiarity of the saying, is still easy to understand. But it is another matter altogether to what extent the promises made in the advert are valid in real life - an aspect that tends to be underestimated while using figurative expressions in the messages targeted at the general public.

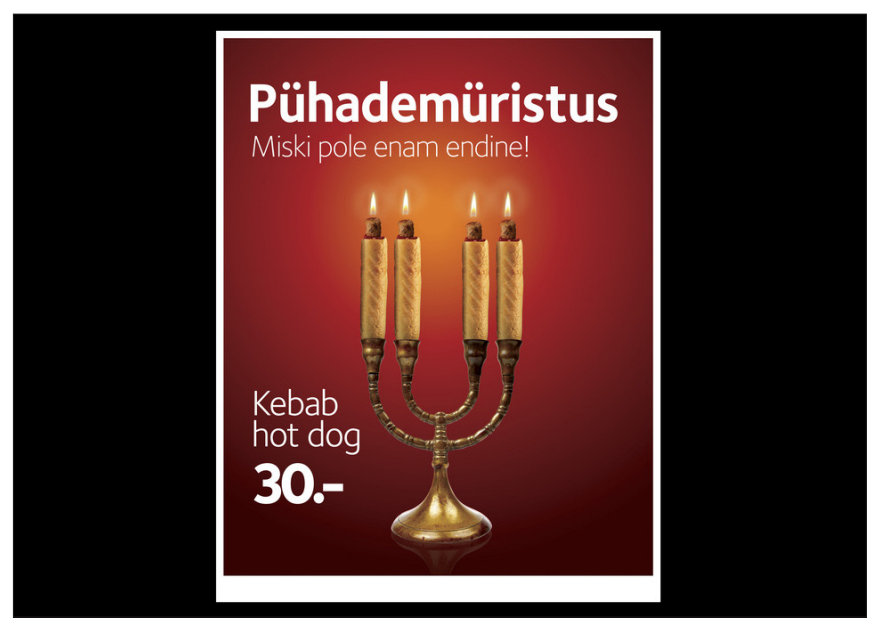

Figure 4. Statoil advertisement.

The following example (Fig. 4) gives an idea of how to forward an extremely multilayered message in advertising. Unlike in the former examples, the phraseologism Pühade müristus! ('Holy thunder/rumble!'; Good Gracious!) in this advert is not directly a source of visualisation. Although the database of Estonian phraseologisms includes only one record of this expression (dating from 1966), which sounds rather archaic, the rhetoric exclamation $O h s a$ püha(de) müristus! ('Oh, holy thunder/rumble!') is frequently encountered in modern language use. If we check earlier lexicographic sources, we can see that this expression is included neither in F. J. Wiedemann's (1973) nor in Andrus Saareste's (1958-1963) dictionaries. It might be a German-origin interjection (cf. Donner und Blitz!). Its modern occurrence is confirmed by the inclusion of 
the expression Sa püha müristus! (You holy thunder/rumble!) (with a remark 'expression of surprise') in the Explanatory Dictionary of Standard Estonian. The noun müristus ('thunder, rumble') is a derivation of the verb müristama ('to thunder, to rumble'), one of the meanings of which is the sound that follows a flash of lightning. As an expression of surprise, it is most probably based on this particular associative meaning. In visual depiction, the authors might possibly have proceeded from the word püha ('holy'), ${ }^{25}$ the more so that this is a Christmas advert. At first sight, the advert combines completely incompatible facets. The exclamation should mark the reaction to a favourable offer as something singular or unheard of - a specifying remark denoting the change compared to the old ('good') times points to this. On the other hand, this 'not like formerly' is manifested in the strangely influential illustration. Namely, a religiously eloquent object is used for visualisation - the menorah from Jewish culture. Yet, in order to forward the message, this is executed in caricatural exaggerated manner (originally, it is a seven-branched candelabrum). One cultural symbol has been converted into a means of advertising for well-known items which belong to other cultural spaces - Turkish kebab and American hot dog. Remarkably, they have selected a meat meal that occupies a special place in Jewish culture. As this is a Christmas campaign (2008), it is even stranger as Jews do not celebrate Christmas. So, this is an advert based on diverse, most controversial links between the text and the picture, the different layers of which can even be unfathomable at first sight. Although the promoted company is again of foreign origin, the local market has used a version created by an Estonian advertising agency, which would have been hardly acceptable in the society emphasising political correctness.

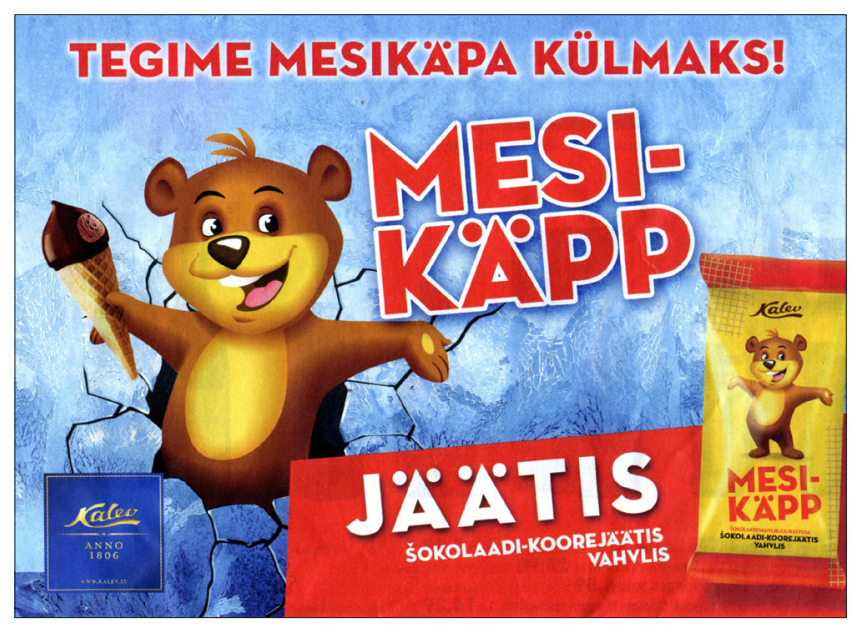

Figure 5. Advertisement for Kalev confectionary. 
The fifth advert is a good example of how you can fail completely if you flirt with the meaning of an expression. The euphemistic name mesikäpp ('Bruin') denoting the bear is also the name of popular local chocolate candy. The aim of the advert was to inform the consumer about releasing the old product in a new form - as an ice-cream. However, the slogan Tegime mesikäpa külmaks! ('We made the Bruin cold!') is ambiguous here. Namely, the figurative meaning of the verbal set expression [kedagi] külmaks tegema ('make someone cold') is 'kill someone' (FS). According to the EKFA, this expression originates from wartime language use (example text: Vaenlased tehti külmaks ('the enemy was made cold')). While the aim was to make the slogan short and striking, the possibility of the figurative level of meaning was not considered. So it happened that a strongly expressive phrase that is also used in prison jargon, made its way into an advertisement targeted at children. This fact evoked a strong negative response both in online and social media. Here are a few examples of headlines and quotes:

- Bruin in choco stick shoes made cold. (Eesti Päevaleht 2011)

- Do we have to interpret the slogan 'We made the Bruin cold!' so that the Kalev Confectionery confesses to murdering a bear? (Meiel 2011)

- The Mesikäpp ice-cream introduced to the market by Kalev is advertised in the streets, and even small children can spell it that the Bruin has been 'made cold' now.

In prison jargon making someone cold means killing them. Let's hope that Bruin is still okay! (Vaene Mesikäpp tehti külmaks! ('The poor Bruin was made cold!') - Vahvel.net 2011)

Maybe unexpected criticism was one of the reasons why the life of this advertisement in the streets was short-termed. In any case, this is a good example of how incompetent use of expressions can result in negative promotion of a company (not necessarily the product). Contrary to the expected results, the failed product promotion drew negative attention to the recognised local enterprise with long-term traditions.

In the case of the last example (Fig. 6) we again have an advertisement in which text is combined with a figurative expression that at first sight is not easily understandable. Actually, the textual part Saiast on siiber. Loodus kutsub ('White bread is a real damper. Nature is calling') is composed of two expressions: [millestki] siiber olema ('to be a damper'; to be fed up with something, have enough of something) (EKSS) and loodus kutsub ('nature is calling') (EESS). While the first expression originates mainly from the youth slang from decades ago (according to EKFA, from the 1990s, but probably even earlier), the specific origin of which is rather vague ${ }^{26}$ then with the second one things are 
somewhat more complicated. In Estonian this expression existed already before the offensive of the English language and therefore it cannot be regarded as a word-for-word translation of the English idiom Mother Nature is calling. ${ }^{27}$ However, the so-called new coming of the expression could have occurred due to the latter's influence. I cannot say whether the copywriters were aware of the other, more ironic meaning of the saying, but in any case they succeeded in combining the figurative expression and the message by way of visualisation (the aim being to encourage inter-Estonian tourism). Similarly to several former examples, the knowledge of cultural context is beneficial in interpreting the visuals supporting the advert message. Differ-

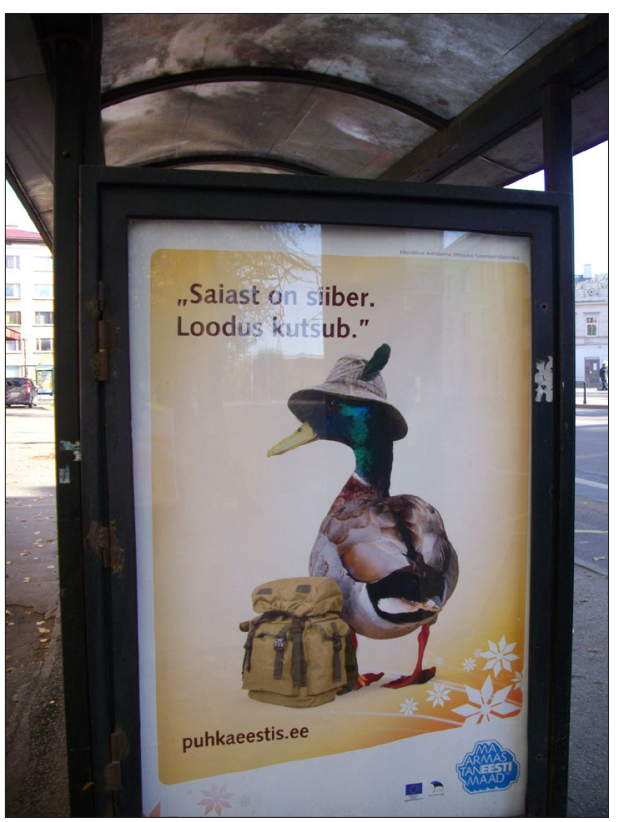

Figure 6. Advertisement of Tourism Development Centre in Tartu. Photo by Anneli Baran 2009. ent multimedia means were applied in this advert - in addition to street advertising also TV-promotion and banners on the Internet. While clicking on the latter, a 'game' opened, which consisted in moving the cursor on the screen (command: Paku pardile saia! ['Feed the duck with white bread']), which in turn opened the main message Puhka Eestis! (Have a break in Estonia!); the aim of the advert was to activate local tourism. ${ }^{28}$

\section{IN CONCLUSION}

When discussing phraseologisms, we usually speak about stability, fixation, and reproducibility - so, it is a linguistic unit excluding any kind of change. The presented examples of co-existence of advertising and phraseologisms are semantic modifications based on ambiguity, with only negligible formal changes. These kinds of playful linguistic deviations constitute a natural part of phraseologism reproduction. On the other hand, phraseological expressions can easily be interpreted by their so-called recipients, which is proved by people's explanations in questionnaires about phraseology. So we can say that an unfamiliar expression is not necessarily incomprehensible. It is the figurativeness of the phraseolo- 
gism that allows for different possible interpretations - namely, visualisation in its processing. While exploring this aspect, we can apply a psycholinguistic approach. A figurative expression generates cognitive activities - finding and constructing meanings. Although the use of phraseology implies the creativity aspect, understanding can be successful only if both parties perceive the wider context, either on conceptual or cultural level. On the other hand, although visualisation can be helpful in understanding, this opportunity also involves artificial exaggeration and manipulation. The nature of this kind of targeted creativity is especially obvious in advertising. From the communicative-pragmatic viewpoint, their main objective is to attract attention, make the recipient indagate and 'decode' the visual image. As was manifest in the presented examples, it is done, as a rule, by way of associative connections. Unfortunately, the user often ignores the fact that the recipient can have a different understanding of the phraseologism. Thus, we can treat the phraseologism as a linguistic sign which, as a complex phenomenon, allows for different interpretations. The visualisation of phraseologisms frequently encountered in advertising is an excellent example of the intertwining of figurativeness and textuality, which is not in the process of becoming but has already become dominant. In further research, we have to establish whether the understanding of visualised texts depends on the existing phraseological competence or it is the general interactive competence that is essential here.

\section{NOTES}

1 Research for this article was supported by the targeted financing project SF0030181s08 (Narrative Aspects of Folklore. Power, Personality and Globalisation) and the state programme project EKKM09-150 (Database of Estonian Sayings and Phraseologisms and Source Publication of Phraseologisms in the Series Monumenta Estoniae Antiquae).

2 The theoretical part of the article is based on the author's doctoral thesis defended in March 2011 (see Baran 2011).

3 Phraseologisms as symbols were discussed in paremiological research already earlier; for example, by paremiologist Grigory Permiakov in the 1960s (see Permiakov 1968).

${ }^{4}$ If we regard phraseologisms as iconic signs, this kind of motivation would sign-theoretically correspond to Ferdinand de Saussure's secondary motivation, this way contradicting arbitrariness as the concept of non-motivatedness of the sign (de Saussure 1966: 133).

5 This concept largely coincides with the contention voiced by Georg Lakoff, the prolocutor of cognitivists, who maintains that although according to so-called classical linguistic approach idioms have arbitrary meanings, then cognitive linguistics claim that they might be not arbitrary but rather prone to motivation; i.e., they are formed 
automatically, by productive rules, yet are adapted to the models offered by the conceptual system (2007: 275).

6 Although in 1996 these researchers set an aim to elaborate criteria to differentiate between the two types of motivation, nine years later they introduced the term blending (Dobrovol'skij \& Piirainen 2005: 103) in the meaning of interaction between different motivation types.

7 In Estonian, alliteration is a frequent formal motivator, especially in phraseological comparisons and word pairs, such as: täis nagu tarakan ('drunk as a cockroach'; drunk as a skunk), saba ja sarvedega ('with tail and horns'; all included), lood ja laulud ('stories and songs').

8 Parallel to the term inner form of the idiom, the authors also use the notion image component (bildliche Bedeutungskomponente / Bildkomponente / bildliche Komponente), the latter meaning a so-called mental image in a cognitive process.

9 An excellent example of the figurativeness of proverbs and sayings is the painting Netherlandish Proverbs (1559) by Pieter Bruegel the Elder, which has given rise to several researches, for example, by Alan Dundes and Claudia A. Stibbe (1981). In more detail, proverb iconography has been discussed by Wolfgang Mieder (2008).

${ }^{10}$ In Estonian, these notions are barely distinguishable: according to EKSS (Dictionary of Estonian Literary Language), the term piltlikkus means 'something represented as a (visual) picture, imagery; metaphorical, figurative', whereas the meaning of visuaalsus is 'figurative, using or including images'.

${ }^{11}$ In Estonian linguistics, iconicity has been defined by Helle Metslang (1993: 204): "Iconicity is an expression of transparency, a phenomenon in which the form reflects the content in a certain sense. With the evolution of languages and their increasing abstractness, iconicity has had to give way to arbitrariness; yet, it is still influential enough, facilitating the reception of information, its processing and transmission."

12 The same complex of notions has also been discussed by cognitivists, with one of the keywords being the more general embodiment, not only the narrow visualisation. Thus, Mark Johnson in his book The Body in the Mind (1987) uses the notion gestalt for experiencing the physical world, which claims that experience is structured already on the pre-linguistic physical plane.

${ }^{13}$ Here we could draw a comparison with Rachel Giora's graded salience hypothesis. According to this, word salience in mental lexicon is influenced by conventionality, frequency, familiarity and prototypicality/stereotypicality (Giora 2003: 15). Thus, this kind of lexicon is also open to change. Contextual influencing factors are regarded as relatively low by Giora.

${ }^{14}$ Another question is to what extent we can make a distinction between text and picture today. David Crystal, who has studied Internet language, has compared the writing style in Internet environment to animated language (2001).

15 The collection competition was organised by the Department of Folkloristics at the Estonian Literary Museum along with the Estonian Folklore Archives. The previous bigger action of the kind took place fifteen years earlier. 
${ }^{16}$ The term was coined by Talis Bachmann and signifies texts that are largely more entertaining than other strategies (Bachmann 2005: 60).

${ }^{17}$ Multimodal aspect in advertisements that makes use of phraseologisms has been discussed in more detail by phraseologist Erla Hallsteinsdóttir (2011).

${ }^{18}$ Although, according to research, the purposeful usage of humour in advertising produces a positive effect, mistakes are easy to occur, and therefore it is recommended to apply it only under restrictions (Bachmann 2005: 98-99).

${ }^{19}$ On advertising perception, incl. the peculiarities of visual perception in advertising, see Bachmann (2005).

${ }^{20}$ Nearly all the mentioned commercials have been awarded the Golden Egg prize by the Estonian Association of Advertising Agencies.

${ }^{21}$ Linguistic means in the language of advertising, incl. the occurrence of verbal forms, as well as sentence structure and textual characteristics, have been discussed in more detail by Reet Kasik (2000).

${ }^{22}$ This example originates from the corpus of old literary Estonian Vakkur. It is interesting to mention that the most important work of earlier lexicography, Ferdinand Johann Wiedemann's Estonian-German Dictionary (first published in 1869) includes merely the expression mustaks lööma (turn black) without an explanatory sample sentence.

${ }^{23}$ Adverts of big international companies are quite different in this respect, as they try to sell their products with one and the same message all over the world or, at the utmost, adapt it to concrete circumstances only to a certain extent (see Leitchik 2006).

${ }^{24}$ The notion of red in the phraseologies of different languages has been discussed by Piirainen \& Dobrovol'skij (1996: 265-267).

${ }^{25}$ Visualisation of one component instead of the whole phraseologism points to the aforementioned peculiarity of phraseological interpretation: this process can be based on the associative links related to a certain lexeme, which can emanate from the ambiguity of the word.

${ }^{26}$ According to Saareste's dictionary (1958-1963), one of the meanings of the Germanorigin word siiber (<der Schieber) is 'damper'; so an explanation for interpreting the expression could be 'get stuck, be damped'.

${ }^{27}$ See: http://www.urbandictionary.com/define.php?term=mother\%20nature\%20is\%20 calling\&defid=5566747, last accessed on February 21, 2013.

${ }^{28}$ This advertisement was part of a longer campaign in which the characters alternated. The commercial released in 2009 was awarded the Golden Egg as one of the best in local advertising market. The version discussed here can be found at http://www.tank. ee/kuldmuna/puhka_eestis_250x250_part.swf, last accessed on October 3, 2012. 


\section{REFERENCES}

Bachmann, Talis 2005. Reklaamipsühholoogia. [Advertising Psychology.] 2nd, supplemented ed. Tallinn: Kirjastus Ilo.

Baran, Anneli 2008. Fraseologismide semantilise teisititõlgendamise võimalikkusest. [On the Semantic Ambiguity of Phraseologisms.] In: Helle Metslang \& Margit Langemets \& Maria-Maren Sepper (eds.) Eesti Rakenduslingvistika Ühingu aastaraamat 4 / Estonian Papers in Applied Linguistics 4. Tallinn: Eesti Keele Sihtasutus, pp. 17-33, doi: http://dx.doi.org/10.5128/ERYa4.02.

Baran, Anneli 2011. Fraseologismide semantika uurimisvõimalused. [Possibilities for Studying Semantics in Phraseology.] Doctoral thesis. Tartu: Tartu Ülikooli Kirjastus.

Baran, Anneli 2012. Visual Humour on the Internet. In: Liisi Laineste \& Dorota Brzozowska \& Władysław Chłopicki (eds.) Estonia and Poland: Creativity and Tradition in Cultural Communication. Volume 1: Jokes and Their Relations.Tartu: ELM Scholarly Press, pp. 171-186, doi:10.7592/EP.1.baran.

Baranov \& Dobrovol'skij 2008 = Baranov, Anatolii \& Dobrovol'skii, Dmitrii 2008. Aspekty teorii frazeologii. [Aspects of Phraseological Theory.] Studia philologica. Moskva: Znak.

Boers, Frank \& Píriz, Ana María Piquer \& Stengers, Hélène \& Eyckmans, June 2009. Does Pictorial Elucidation Foster Recollection of Idioms? Language Teaching Research, Vol. 13 (4), pp. 367-382, doi:10.1177/1362168809341505.

Burger, Harald 1973. Idiomatik des Deutschen. Unter Mitarbeit von Harald Jaksche. Tübingen: Niemeyer.

Burger, Harald 2003. Phraseologie. Eine Einführung am Beispiel des Deutschen. Berlin: Erich Schmidt.

Cacciari, Cristina \& Glucksberg, Sam 1995. Imagining Idiomatic Expressions: Literal or Figurative Meanings? In: Martin Everaert \& Erik-Jan van der Linden \& André Schenk \& Rob Schreuder (eds.) Idioms: Structural and Psychological Perspectives. Hillsdale: Erlbaum, pp. 43-56.

Crystal, David 2001. Language and the Internet. Cambridge: Cambridge University Press.

Dobrovol'skij, Dmitrij 1997. Idiome in kognitiver Perspektive. Zur Begriffsbestimmung. In: Mariann Skog-Södersved (ed.) Ethische Konzepte und mentale Kulturen 1. Auf der Suche nach ethischen Konzepten in Wortschatz und Phraseologie. Acta Universitatis Umensis, Umea Studies in the Humanities 139. Umeå: Umea University Press, pp. 17-57.

Dobrovol'skij, Dmitrij \& Piirainen Elisabeth 1996. Symbole in Sprache und Kultur. Studien zur Phraseologie aus kultursemiotischer Perspektive. In: Wolfgang Eismann \& Peter Grzybek \& Wolfgang Mieder (eds.) Studien zur Phraseologie und Parömiologie. Bochum: N. Brockmeyer.

Dobrovol'skij, Dmitrij \& Piirainen, Elisabeth 2005. Figurative Language: Cross-Cultural and Cross-Linguistic Perspectives. Current Research in the Semantics / Pragmatics Interface, Vol. 13. Amsterdam [etc.]: Elsevier.

Dobrovol'skij, Dmitrij \& Piirainen, Elisabeth 2009. Zur Theorie der Phraseologie. Kognitive und Kulturelle Aspekte. Tübingen: Stauffenburg Verlag. 
Dundes, Alan \& Stibbe, Claudia A. 1981. The Art of Mixing Metaphors. A Folkloristic Interpretation of the Netherlandish Proverbs by Pieter Bruegel the Elder. FF Communications, No. 230. Helsinki: Suomalainen Tiedeakatemia.

EKFA = Baran, Anneli \& Hussar, Anne \& Õim, Asta \& Õim, Katre (comps.) Eesti kõnekäändude ja fraseologismide andmebaas 1998-2005. [Database of Estonian Proverbs and Phraseologisms 1998-2005.] Available at http://www.folklore.ee/ justkui, last accessed on February 27, 2013.

EKSS = Eesti kirjakeele seletussõnaraamat I-VII. [Explanatory Dictionary of Standard Estonian.] Tallinn: Eesti Keele Instituut 1988-2007.

EESS = Loog, Mai 1991. Esimene eesti slängi sõnaraamat. [First Estonian Slang Dictionary.] Tallinn: Mai Loog. Available at http://www.eki.ee/dict/slang/, last accessed on February 27, 2013.

Farø, Ken 2006. Ikonographie, Ikonizität und Ikonizismus: Drei Begriffe und ihre Bedeutung für die Phraseologieforschung. Available at http://www.linguistik-online. de/27_06/faroe.html, last accessed on February 27, 2013.

Fiedler, Sabine 2010. Phraseology in a time of crisis. Yearbook of Phraseology, Vol. 1, pp. 1-17, doi:http://dx.doi.org/10.1515/9783110222623.1.1.

Forceville, Charles 1994. Pictorial Metaphor in Advertisements. Metaphor and Symbolic Activity, Vol. 9 (1), pp. 1-29, http://dx.doi.org/10.1207/s15327868ms0901_1.

FS = Õim, Asta 1993. Fraseoloogiasõnaraamat. [Dictionary of Estonian Phraseologisms.] Tallinn: Keele ja Kirjanduse Instituut.

Gibbs, Raymond W. Jr. 1989. Understanding and Literal Meaning. Cognitive Science, Vol. 13, pp. 243-251, http://dx.doi.org/10.1016/0364-0213(89)90006-2.

Gibbs, Raymond W. Jr. 1994. The Poetics of Mind: Figurative Thought, Language, and Understanding. Cambridge [etc.]: Cambridge University Press.

Gibbs, Raymond W. Jr. 1998. The Fight over Metaphor in Thought and Language. In: Cristina Cacciari \& Albert N. Katz \& Mark Turner \& Raymond W. Gibbs, Jr. (eds.) Figurative Language and Thought. Oxford: Oxford University Press, pp. 88-118.

Gibbs, Raymond W. Jr. 2002. A new look at literal meaning in understanding what is said and implicated. Journal of Pragmatics, Vol. 34 (4), pp. 457-486, http://dx.doi. org/10.1016/S0378-2166(01)00046-7.

Giora, Rachel 2003. On Our Mind: Salience, Context, and Figurative Language. Oxford: Oxford University Press.

Häcki Buhofer, Annelies 1999. Psycholinguistik und Phraseologie. In: Nicole FernandezBravo \& Irmtraud Behr \& Claire Rozier (eds.) Phraseme und typisierte Rede. Tübingen: Stauffenburg, pp. 63-75.

Hallsteinsdóttir, Erla 2011. Aktuelle Forschungsfragen der deutschsprachigen Phraseodidaktik. Linguistik online 47 (3). Available at http://www.linguistik-online. de/47_11/hallsteinsdottir.html, last accessed on February 2, 2013.

Johnson, Mark 1978. The Body in the Mind: The Bodily Basis of Meaning, Imagination, and Reason. Chicago: University of Chicago Press.

Kasik, Reet 2000. Reklaamikeel tekstiliigina. [Advertising Language as a Text Type.] In: Tiit Hennoste (ed.) Eesti keele allkeeled. [Sublanguages of Estonian.] Tartu Ülikooli eesti keele õppetooli toimetised 16. Tartu: Tartu Ülikool, pp. 111-127. 
Krikmann, Arvo 2004. Koestler, Raskin, Attardo ja teised: Lingvistiliste huumoriteooriate uuemaist arenguist. [Koestler, Raskin, Attardo and Others: Recent Developments of Linguistic Humour Theories.] Reetor 4. Tartu: Eesti Kirjandusmuuseum.

Laaniste, Mari 2005. Piltide ja kirja keelest. [On the Language of Pictures and Script.] Keel ja Kirjandus, Vol. 8, pp. 617-629.

Lakoff, George 2007. The Contemporary Theory of Metaphor. In: Vyvyan Evans \& Benjamin K. Bergen \& Jörg Zinken (ed.) The Cognitive Linguistics Reader. London \& Oakville: Equinox, pp. 267-315.

Leichik, Vladimir Moiseevich 2006. Iazyk reklamy v kontekste globalizatsii i etnizatsii. [Advertising Language in the Context of Globalisation and Ethnicisation.] In: G. P. Neshchimenko (resp. ed.) Globalizatsiia - etnizatsiia: Etnokul'turnye i etnoiazykovye protsessy: $v$ 2-kh kn. Moskva: Nauka, Kn. 1, pp. 447-475.

Levorato, Maria Chiara \& Cacciari, Cristina 1999. Idiom Comprehension in Children: Are the Effects of Semantic Analysability and Context Separable? European Journal of Cognitive Psychology, Vol. 11 (1), pp. 51-66, http://dx.doi.org/10.1080/713752299.

Lotman, Iurii 1981. Rhetoric. In: Struktura i semiotika khudozhestvennogo teksta. [Structure and Semiotics of Literary Text.] Trudy po znakovym sistemam XII. Tartu: Tartuskii gosudarstvennyi universitet, pp. 8-28.

Metslang, Helle 1993. Verbitarind ajatähendust väljendamas. [Verb Forms Expressing Time.] Virittäjö. Kotikielen seuran aikakauslehti 97, pp. 203-221. Available at http://www.kotikielenseura.fi/virittaja/hakemistot/jutut/1993_203.pdf, last accessed on February 4, 2013.

Mieder, Wolfgang 2008. "Proverbs Speak Louder Than Words". Folk Wisdom in Art, Culture, Folklore, History, Literature, and Mass Media. New York: Peter Lang Publishing.

Naciscione, Anita 2010. Visual Representation of Phraseological Image. In: Koenraad Kuiper (ed.) Yearbook of Phraseology 1. Kemptnen: De Gruyter Mouton, pp. 19-43, http://dx.doi.org/10.1515/9783110222623.1.19.

Nayak, Nandini P. \& Gibbs, Raymond W. Jr. 1990. Conceptual Knowledge in the Interpretation of Idioms. Journal of Experimental Psychology: General, Vol. 119 (3), pp. 315-330, http://dx.doi.org/10.1037//0096-3445.119.3.315.

Permiakov, Grigorii 1968. Izbrannye poslovitsy i pogovorki narodov Vostoka. [Collection of Proverbs and Sayings from the Peoples of the Orient.] Moskva: Nauka.

Piekot, Tomasz 2012. Pictorial Representation of Idioms in Internet Humour. In: Liisi Laineste \& Dorota Brzozowska \& Władysław Chłopicki (eds.) Estonia and Poland: Creativity and Tradition in Cultural Communication. Volume 1: Jokes and Their Relations.Tartu: ELM Scholarly Press, pp.187-203, doi:10.7592/EP.1.piekot.

Röhrich, Lutz 1973. Lexikon der sprichwörtlichen Redensarten. Freiburg: Herder.

Röhrich, Lutz 1978. Sprichwörtliche Redensarten in bildlichen Zeugnissen. In: Wolfgang Mieder (ed.) Ergebnisse der Sprichwörterforschung. Europäische Hochschulschriften, Vol. 192. Bern: Verlag Peter Lang, pp. 87-107.

Saareste, Andrus 1958-1963. Eesti keele mõisteline sõnaraamat I-VI. [Thesaurus of the Estonian Language.] Stockholm: Vaba Eesti.

Sarapik, Virve 1998. Punane. Sõna ja värv. [Red. Word and Colour.] Sator 1. Artikleid usundi- ja kombeloost. Tartu: Eesti Keele Instituut, pp. 7-37. Available at http:// 
www.folklore.ee/rl/pubte/ee/sator/sator1/sator1-1.pdf, last accessed on February 4, 2013.

Saussure, Ferdinand de 1966. Course in General Linguistics. New York: McGraw-Hill Book Company.

Szczepaniak, Renata \& Lew, Robert 2011. The Role of Imagery in Dictionaries of Idioms. Applied Linguistics, Vol. 32 (3), pp. 323-347, http://dx.doi.org/10.1093/applin/ amr001.

Tendahl, Markus \& Gibbs, Raymond W. Jr. 2008. Complementary Perspectives on Metaphor: Cognitive Linguistics and Relevance Theory. Journal of Pragmatics, Vol. 40 (11), pp. 1823-1864, http://dx.doi.org/10.1016/j.pragma.2008.02.001.

Torop, Peeter 2008. Multimeedialisus. [Multimediality.] Keel ja Kirjandus, Vol. 8/9, pp. 721-734. Available at http://keeljakirjandus.eki.ee/721-734.pdf, last accessed on February 4, 2013.

Vakkur = Vana kirjakeele korpus. [Corpus of Old Literary Estonian.] Available at http:// www.murre.ut.ee/vakkur/Korpused/korpused.htm, last accessed on February 1, 2013.

Varga, Éva 2010. (K)ein Grund zum Lachen! Phraseologische Modifikation in der Werbesprache. In: Anna T. Litovkina \& Péter Barta \& Margit Daczi (eds.) Linguistic Shots at Humour. Humour and Culture 1. Kraków: Tertium, pp. 209-226.

Vinogradov, Viktor 1947. Ob osnovnykh tipakh frazeologicheskikh edinits v russkom iazyke. [On the Main Types of Phraseological Units in Russian.] In: A. A. Shakhmatov. 1864-1920. Sbornik statei i materialov. Ed. by S. P. Obnorskii. Trudy komissii po istorii Akademii nauk SSSR, vyp. 3. Moskva \& Leningrad: Izd-vo Akademii nauk SSSR, pp. 339-364.

Wiedemann, Ferdinand Johann 1973. Eesti-saksa sõnaraamat. [Estonian-German Dictionary.] 4th, unchanged edition of the 2nd edition revised by Jakob Hurt. Tallinn: Valgus.

\section{INTERNET SOURCES FOR LINGUISTIC EXAMPLES}

Eesti Päevaleht 2011. http://www.epl.ee/news/melu/kulmaks-tehtud-mesikappbatoonkingades.d?id=51300222, last accessed on April 1, 2013.

Fazer 2012. http://mustleib.fazer.ee/?utm_source=delfi.ee\&utm_medium=sitehat_ banner\&utm_campaign=must_leib, last accessed on April 1, 2013.

Henri Jääger 2008. http://reklaam.postimees.ee/?op=body\&id=162\&cid=100\&cgid, last accessed on April 1, 2013.

Meiel 2011. http://twitter.com/\#!/kaupomeiel/status/82166954776989696, last accessed on April 1, 2013.

Vahvel.net 2011. http://vahvel.net/showthread.php?131744-Vaene-Mesik\%E4pp-tehtik\%FClmaks!\&highlight=mesik\%E4pp, last accessed on April 1, 2013. 